\title{
Notes on the Role of Judicial Review, the Expansion of Federal Power, and the Structure of Constitutional Rights
}

\author{
Constitutional Cultures: The Mentality and Consequences of \\ Judicial Review. By Robert F. Nagel.* Berkeley: University of \\ California Press, 1989. Pp. xi, 232.
}

\section{Douglas Laycock $\uparrow$}

Constitutional Cultures contains many shrewd insights, and at least one spectacular insight. Every lawyer interested in the Constitution should read it. But read it only for specific insights, taken one at a time. The theory by which Nagel tries to unify these insights is part of the problem, not a step towards a solution.

Thus, the book's whole is very much less than the sum of its parts. The insights are interspersed with polemic against judicial review in general and liberal judges in particular, blaming judges for all our constitutional ills and most constitutional change. The polemic is supported by a remarkably selective marshalling of history and examples.

The book is difficult to summarize, in part because of its inductive style, and in part because it finds so many different things wrong with judicial review. The power of Nagel's argument is in his cumulation of examples of judicial review being done in ways he does not like. But not all of the examples seem consistent. Thus, he generally attacks the Court for trying to do too much, but he sometimes attacks the Court for doing too little. ${ }^{1} \mathrm{He}$ offers only the most conclusory statement of what he thinks the Court should do instead, ${ }^{2}$ and gives no hint of how the Court should explain the results he would prefer. It is not clear whether he thinks that

\footnotetext{
* Moses Lasky Professor of Law, University of Colorado School of Law.

$\dagger$ Alice McKean Young Regents Chair in Law, The University of Texas at Austin. I am grateful to Harold Bruff, Sanford Levinson, L.A. Powe, and Jay Westbrook for helpful comments on earlier drafts, and to Dana Elfin for research assistance. This Book Review adheres to The Yale Law Journal's custom of capitalizing "Federal" and of not capitalizing "state." This is not my custom, and I do not intend any implication about the relative dignity of state and Federal governments.

1. R. Nagel, Constitutional Cultures: The Mentality and Consequences of JudiCIAL REVIEW 27, 55-57, 60-61 (1989) [hereinafter cited by page number only].

2. P. 3 .
} 
almost nothing is unconstitutional, or that almost nothing is justiciable. He seems to think both.

The book consists mostly of material published earlier in article form, with very little apparent revision; only chapter 1 is new. The unifying theme is that each chapter is about some problem that Nagel attributes to the judicial "mentality." This is a broad umbrella, and it shelters what seem to me to be two distinct parts. Nagel argues that courts reach bad results in constitutional cases (chapters 1-4) and that they write bad opinions (chapters 5-7), and that each of these defects is inherent in the judicial process.

With respect to results, Nagel argues that the adversarial process and the training of lawyers are inherent sources of doctrinal instability. ${ }^{3}$ Lawyers are trained to invent new arguments and to distinguish old precedents. They are committed to rational argument, and thus are hostile to traditional values rooted more in human experience than in logic. ${ }^{4}$ For both of these reasons, judges are the last people who should be entrusted with preservation of fundamental values: "[T]he special function of the judiciary is to change constitutional meaning."' Nagel concludes that the Constitution fares much better when judges do not enforce it. ${ }^{6}$

Consequently, judges should assume a much smaller constitutional role. They should hold governmental actions unconstitutional only when those actions are "emphatically inconsistent with constitutional theory, text, and public understanding as expressed in prolonged practice." " Nagel especially hates "the routinization of judicial power" and the "judiciary's frequent intervention in ordinary political affairs." $\mathrm{He}$ apparently would have the Court issue an occasional pronouncement, in an especially egregious case, reminding the states and the other two branches that they should respect constitutional rights. ${ }^{9}$ Then the judiciary should withdraw, leaving implementation of the Constitution to other units of government. Nagel would reduce all of judicial review to what Philip Bobbitt calls the "expressive function." "10

Nagel is more effective when he criticizes judicial opinions. He shows, with detailed illustrations, that Supreme Court opinions tend to be detached from the facts of cases. ${ }^{11}$ The opinions focus on what is rational and on connections between means and ends, but they tend to avoid ex-

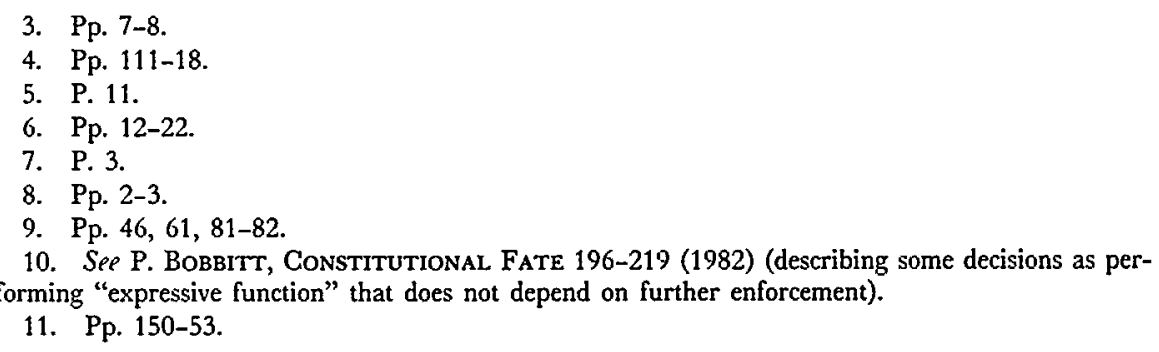


plicit discussion of the real competing interests at stake. ${ }^{12}$ Their analysis of rationality and of means and ends is often artificial and distorted, sometimes even dishonest. Every constitutional inquiry is soon reduced to a multi-part test, which largely substitutes for the constitutional text. This observation leads to the title of chapter 7, The Formulaic Constitution, and forms the basis of the insight I consider spectacular. The Justices of the Supreme Court, and their law clerks, should be required to read and meditate on this chapter at frequent intervals-say the first Monday of every month.

This review will range as widely as Nagel's book, exploring fundamental issues of constitutional method as well as the details of Nagel's argument. The review has three independent parts. First, I respond to Nagel's substantive attack on judicial review. I concede many of his examples and criticisms, but dispute others, and highlight examples that he ignores. I argue that Nagel misunderstands the role of judges, misunderstands the justifications for judicial review, and misunderstands the Constitution.

Second, I argue that the vast expansion of Federal power since the founding is firmly rooted in constitutional text, and that it is not the product of usurpation or judicial manipulation. This is a special case of my response to Nagel's substantive attack on judicial review.

Finally, I endorse much of Nagel's criticism of judicial opinions, but I argue that the style of argument in Supreme Court opinions is largely a response to Nagel's own brand of criticism of the Court. For decades, people like Nagel have been telling judges that they are not supposed to decide questions of substance, that they are not supposed to balance competing interests and that they are not supposed to do anything important. Many judges have internalized these views. In so doing, they ignore the structure of constitutional rights, which requires them to do exactly what Nagel would forbid.

The Justices are charged with enforcing a Constitution that expressly creates sweeping substantive rights. The government constantly demands implied exceptions to these rights. Thus, the analytic structure of constitutional rights forces the Court to decide important questions of substance, balancing the need for implied exceptions against the literal demands of the Constitution. The Court should have explicitly acknowledged the necessity of tackling substantive issues, and challenged its critics head on, but it has not. Instead, it takes refuge in the artificial analyses that Nagel decries, concealing substantive issues in clouds of technical rhetoric and multi-tiered tests. Nagel is hardly entitled to complain.

12. P. 105 . 


\section{The Role of Judicial Review}

In the first four chapters, Nagel develops the substantive argument that judicial review cannot work. Most of the general argument appears in chapter 2; chapters 3 and 4 attempt to illustrate it in the areas of free speech and federalism. Chapter 1 is a short apologia, conceding that Brown v. Board of Education ${ }^{13}$ was a good thing even though Nagel cannot justify it. He claims only that Brown was more nearly justifiable than most of what the Court does, ${ }^{14}$ but that one spectacular success cannot justify an institution that generally does more harm than good. Even the whims of a tyrant will occasionally produce a good result. ${ }^{15}$ That does not justify tyranny, any more than Brown alone justifies judicial review.

\section{A. The General Argument}

Nagel's attack on judicial review combines familiar arguments with real insights. The Supreme Court's actual track record is mixed. Successes like Brown are balanced by disasters like Dred Scott ${ }^{\mathbf{1 6}}$ even the success of Brown was dissipated in the miasma of busing. ${ }^{17}$ For long periods the Court has been hostile to civil liberties instead of protective. ${ }^{18}$ Major doctrines are adopted, abandoned, and even reversed; the courts have not provided doctrinal stability. ${ }^{10}$ Ultimately, Nagel concludes that the legal system cannot provide stability, because the adversary system encourages the continuous search for novel arguments. ${ }^{20}$

Judicial decisions sometimes focus issues and sharpen controversies that might otherwise be left vague and neglected. Politicians and elected officials can finesse controversies with fuzzy language, by avoiding statements of principle, by agreeing on the result without agreeing on reasons, or by not offering reasons at all. Politicians can also engage in occasional emergency suppression without publishing records, without stating formal justifications, and without treating their actions as precedent. ${ }^{21}$ Judges have much more difficulty using these techniques. Courts must give reasons, articulate general principles, and live with their precedents. ${ }^{22} \mathrm{~A}$ series of cases will pressure courts to draw precise lines-to say that this plaintiff wins and that a similar but not quite identical plaintiff loses. Judicial

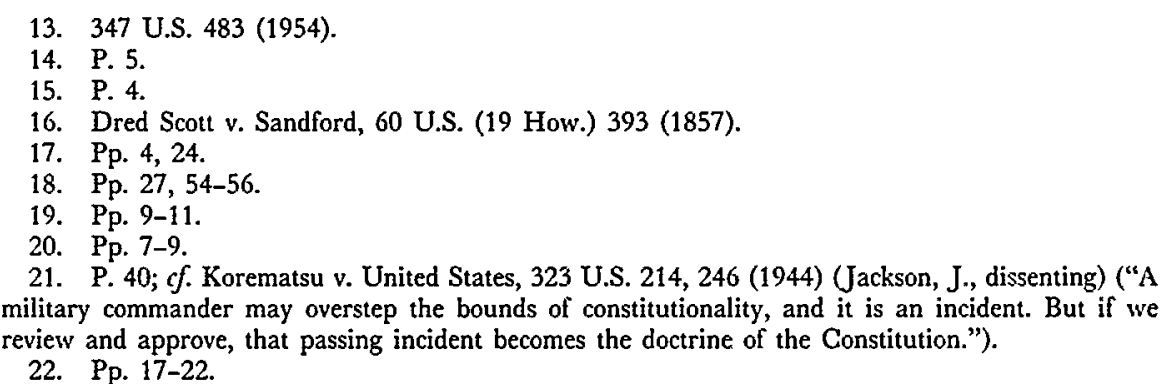

22. Pp. 17-22. 
emphasis on principle tends to push arguments to their limit instead of toward acceptable compromise. ${ }^{23}$

Nagel also scores a point when he notes that most constitutional theorists tend to de-emphasize the actual record of judicial review and instead defend it in principle. Theorists focus on the intellectual issues, and they are "captured by the lure of the possible." 24 To elaborate on Nagel's point, each theorist believes the Gourt would do much better if it would just adopt the right constitutional theory and consistently apply it. Each theorist believes that if he had five votes on the Court, he would decide cases consistently and coherently. $\mathrm{He}$ would be right in principle and would focus on the right issues, though of course there would be close cases, and he would make mistakes at the margin. Many theorists are even right in these high opinions of their own theory. If coherence and stability are the criteria, almost any consistently applied theory could do better than the Court has done.

The essential fact is that no one person does have five votes on the Court, and no one person has even a single vote permanently. This reduces the risks of tyranny and of idiosyncratic decisions, but it substitutes other insoluble problems. The Justices come to the Court with very different views of the Constitution; they must combine these views into group decisions. Inconsistency and instability are inherent in group decision-making. The reasons have been formally explained by Kenneth Arrow and others, ${ }^{25}$ and Judge Easterbrook has applied this analysis to the work of the Supreme Court. ${ }^{26}$ The reasons are captured informally in the folk saying that a camel is a horse designed by a committee. Constitutional doctrine is the Supreme Court's camel, and from every point on the political spectrum, critics find it lumpy and ungainly. On this point, all the critics are right, and the situation will not improve.

But Nagel does not mention the problems inherent in group decisionmaking. These problems are equally applicable to the political branches, so they do not serve his end of showing that courts are uniquely ill-suited to decide anything important.

Nagel turns instead to selective constitutional history to support his claim that the Court's work has been generally harmful. He claims that the constitutional provisions that have worked well are those the Court has not interpreted. He offers such examples as the republican form clause, the advice and consent clause, the provisions for elections and terms of office, and the qualifications for office. He claims that constitu-

23. Pp. $20,38-40$.

24. P. 4; set also pp. 31-34 (reviewing two generations of scholars who severely criticized judgemade law of free speech while at same time looking to judges for solution).

25. See K. Arrow, Social Choice and Individual Values (2d ed. 1963). For surveys of the literature, see D. MUELL.ER, PuBlic ChoICE (1979); Farber \& Frickey, The Jurisprudence of Public Choice, 65 TEX. L. REv. 873 (1987).

26. Easterbrook, Ways of Criticizing the Court, 95 Harv. L. Rev. 802 (1982). 
tional meaning that emerges from practice is stable and widely accepted; ${ }^{27}$ constitutional meaning that is announced by courts is unstable and controversial. He carefully anticipates and refutes several arguments that the uninterpreted clauses are different in kind from the interpreted clauses. ${ }^{28}$

Unfortunately, he ignores other obvious objections. In part, he inverts cause and effect. It is not that some clauses have had stable and uncontroversial meanings because they were never litigated. Rather, some clauses had stable and uncontroversial meanings, and, because they had such meanings, those clauses were never litigated. The engine of constitutional change is not judges, but controversy. Judges sometimes aggravate controversy, but they hardly ever start it.

Other rarely litigated clauses produced controversies that the Court refused to decide, with disparate results. Sometimes the Court's refusal to enforce a clause kills the clause, in the sense that participants in public disputes quit appealing to it. Most obviously, this is what happened to the privileges or immunities clause of the Fourteenth Amendment. ${ }^{29}$

But sometimes, the Court's refusal to enforce a clause simply moves the dispute to other forums, with no reduction in controversy and no increase in stability. Thus, disputes over constitutional amendments are nonjusticiable, ${ }^{30}$ but bitter controversy continues over many aspects of the amendment process: repeated ratification votes, rescission of ratifications, time limits for ratification, extension of time limits, when Congress must call a convention, whether a convention can be limited to a single subject, and so on. ${ }^{31}$ The Court's refusal to adjudicate anything about the amendment process has even facilitated arguments that the Article $\mathrm{V}$ amendment process is not exclusive. ${ }^{32}$

The republican form clause has experienced both phenomena: dormant and ignored in normal times, but a wholly unpredictable source of controversial power in extraordinary times. The republican form clause supplied much of the constitutional theory for congressional reconstruction of state government in the defeated South. ${ }^{33}$

27. Pp. 12-14.

28. Pp. 14-17.

29. See L. Tribe, American Constitutional Law § 7-4 (1988).

30. See Coleman v. Miller, 307 U.S. 433 (1939).

31. For debate on these issues, see R. Caplan, Constitutional. Brinksmanship: Amending the Constrtution by National Convention (1983); Dellinger, The Legitimacy of Constitutional Change: Rethinking the Amendment Process, 97 HARv. L. REv. 386 (1983); Rees, Throwing Auray the Key: The Unconstitutionality of the Equal Rights Amendment Extension, 58 TEx. L. REv. 875 (1980); Tribe, A Constitution We Are Amending: In Defense of a Restrained Judicial Role, 97 HaRv. L. Rev. 433 (1983).

32. See Ackerman, Constitutional Politics/Constitutional Law, 99 Yale L.J. 453, 491-98 (1989); Amar, Philadelphia Revisited: Amending the Constitution Outside Article V, 55 U. CHI. L. REv. 1043 (1988).

33. See E. Foner, Reconstruction: America's Unfinished Revolution, 1863-77, at 232, 272 (1988). For an account of the Southern theory of the clause, see Vile, John C. Calhoun on the Guarantee Clause, 40 S.C.L. REv. 667, 676-82 (1989). 
Three distinct claims are embedded in Nagel's comparison of constitutional law made by courts and constitutional law made without courts. $\mathrm{He}$ claims that when courts stay out of an issue, the resulting constitutional law is i) stable and ii) satisfactory. He also claims iii) that when courts do undertake to enforce a clause, and doctrine changes, the courts are the cause of the change. He ignores powerful counter-examples on all three points, and, his third point overlooks the whole political process.

With respect to the claim of stability, consider relations between the President and the Congress. The Court has largely left that relationship to the political process, intervening only sporadically. Yet, as Nagel frankly acknowledges, ${ }^{34}$ there have been large fluctuations in the relative constitutional power of the other two branches, ${ }^{36}$ resulting in both congressional government and imperial presidencies. For example, Woodrow Wilson wrote his famous book describing how checks and balances had given way to congressional supremacy, ${ }^{36}$ but in a new preface only fifteen years later, he wrote that power had shifted dramatically to the executive. ${ }^{37}$ Likewise, Supreme Court decisions did not cause the difference between Andrew Johnson's power in 1866 and Lyndon Johnson's in 1966.

Practice on important matters has developed, changed, and changed back again. The long-term struggle for control of foreign affairs has barely been influenced, and certainly not abated, by judicial deference. Power shifts of constitutional significance have been accomplished by statutes, such as the Budget $\mathrm{Act}^{38}$ and the War Powers Resolution, ${ }^{39}$ as well as by accumulating practice, such as executive agreements ${ }^{40}$ and administrative agencies. ${ }^{41}$

The history of the constitutional rights of blacks is even more telling: Judicial deference produced results that were neither stable nor satisfactory. Except for a handful of narrow Supreme Court decisions, the rights of blacks were largely left to the political process from about 1860 to about $1950 .{ }^{42}$ By Nagel's theory, the constitutional provisions guarantee-

\footnotetext{
34. P. 22.

35. Sie J. Choper, Judicial, Review and the National Political Process 289 (1980); A. Schlesinger, The Imperial Presidency (1973); P. Shane \& H. Bruff, The Law of PresidenTIAL. POWER 12-20 (1988).

36. W. Wilson, Congressional Government (1st ed. 1885).

37. Id. at xi-xiii (15th ed. 1900).

38. Congressional Budget and Impoundment Control Act of 1974, Pub. L. No. 93-344, 88 Stat. 297 (codified as amended in scattered sections of 1,2 \& 31 U.S.C.).

39. War Powers Resolution of 1973, Pub. L. No. 93-148, 87 Stat. 555 (codified as amended at 50 U.S.C. \$\$ 1541-1548 (1988)).

40. Sep J. Choper, supra note 35, at 356-57; A. Schlesinger, supra note 35 , at 85-88, 105-09, 311-16.

41. For analyses of the constitutional role of agencies, see Bruff, Presidential Power and Administratiz'e Rulemaking, 88 YALE L.J. 451 (1979); Strauss, The Place of Agencies in Goternment: Separation of Pouters and the Fourth Branch, 84 CoLum. L. REv. 573 (1984). Ira Lupu adds to this example the recent reassertion of presidential control over agencies. Lupu, When Cultures Collide (Book Review), 103 HaRv. L. REv. 951, 955 (1990).

42. Ser, e.g., Missouri ex rel. Gaines v. Canada, 305 U.S. 337 (1938) (requiring state to provide
} 
ing the rights of blacks should have been a great success in that period. We should have had stable constitutional meaning with little controversy, and basic constitutional rights should have been broadly respected.

In fact, the results were neither stable nor satisfactory. There was dramatic growth in constitutional doctrine during the Givil War and Reconstruction-all coming from the political branches and eventually written into the Constitution by coerced ratification of the Reconstruction Amendments. ${ }^{43}$ The war was followed by eleven years of vigorous but gradually declining congressional commitment to the constitutional rights of blacks. ${ }^{44}$ Then, in 1876, the Federal Government abandoned blacks to their fate: the political branches dramatically reversed their constitutional policy. There ensued seventy-five years of relative stability, massive oppression, and wholesale constitutional violations. The Supreme Court kept its hands off, narrowly interpreting the privileges or immunities clause, ${ }^{45}$ the equal protection clause, ${ }^{46}$ and the Civil Rights Act, ${ }^{47}$ so that it had nothing left to enforce. But judicial abdication did not produce the satisfactory results that Nagel's theory predicts.

Similarly, the courts stayed out of legislative apportionment until the 1960 's. ${ }^{48}$ Despite unambiguous mandates in many state constitutions for periodic apportionment on the basis of population, most state legislatures were grossly malapportioned. ${ }^{49}$ Small minorities of the population controlled a majority of legislative seats in perpetuity, with no prospect that they would ever relinquish that control voluntarily. The situation had persisted for decades, and had gotten steadily worse. Doctrine was stable, but one can hardly claim that results were satisfactory.

Nagel's most serious error is the claim I have numbered (iii), attributing constitutional change to the judiciary. In fact, such changes often-and major changes always-originate off the Court. Great lonsterm changes in constitutional doctrine result from great long-term shitts in political balance.

Consider constitutional history since the New Deal. The New Deal

law school for blacks); Buchanan v. Warley, 245 U.S. 60 (1917) (invalidating zoning law forbidding blacks to live in white neighborhoods); Guinn v. United States, 238 U.S. 347 (1915) (invalidating literacy test for voting with grandfather clause for whites); Strauder v. West Virginia, 100 U.S. 303

(1879) (reversing criminal conviction of black tried before jury from which blacks had been excluded).

43. For a brief description of the ratification process, see Ackerman, supra note 32, at 500-07.

44. The best study of this period is E. FonER, supra note 33 .

45. The Slaughter-House Cases, 83 U.S. (16 Wall.) 36 (1872).

46. Plessy v. Ferguson, 163 U.S. 537 (1896).

47. The Civil Rights Cases, 109 U.S. 3 (1883).

48. Compare Reynolds v. Sims, 377 U.S. 533 (1964) (invalidating malapportionment of congressional districts) and Baker v. Carr, 369 U.S. 186 (1962) (apportionment questions are justiciable) with Colegrove v. Green, 328 U.S. 549 (1946) (apportionment questions are nonjusticiable).

49. For summary data on each state as of 1963-64, see R. MCKAY, Reapportionment: The LAW AND Politics of EQUAL RePResentation 46-47 (1965). For the specific constitutional requirements in each of these states, disregarding general provisions such as equal protection clauses, see id. at $460-75$. 
brought massive shifts in constitutional doctrine, shifts that expanded Federal power, largely ended judicial review of economic regulation, and began a new era of protection for civil liberties. Nagel offers the expansion of Federal power as one of the most fundamental constitutional changes. ${ }^{50}$ Bruce Ackerman describes the New Deal changes as a constitutional transformation, a massive but implicit constitutional amendment, ratified in the election of $1936 .{ }^{51}$ No one denies that these changes were large and important. But for Nagel to attribute them to judges is nonsense. These changes were initiated by the political branches and pushed through despite vigorous resistance by the Supreme Court.

Eventually the Court acquiesced in the new constitutional theory, and after the newly dominant political coalition appointed a majority of the justices, the Supreme Court began to take its own initiatives in line with the new theory. There followed half a century of right-wing criticism of the Supreme Court. Appointments to the Court have been a significant issue in most recent presidential elections, beginning with Richard Nixon's promise to make judicial appointments that would "strengthen the peace forces." (He meant the police, not the war protesters.) This long conservative campaign may at last have created, beginning with October Term 1988, a reliable new Supreme Court majority on a wide range of issues. Given the age distribution of the current Justices, the Republican ascendancy in presidential elections, and the Court's significance to an important part of the Republican coalition, this new majority may persist for the foreseeable future. If so, we may see major changes in constitutional doctrine.

Nagel's claim that judicial abdication yields doctrinal stability implies that without judicial review, such changes would not occur at all. But this is utter nonsense. Such a claim ignores the fifty-year political campaign to change the Court's membership, just as Nagel's account of doctrinal change in the New Deal ignores the long campaigns of the Progressives and Realists to alter the Court's membership. Nagel ignores how Justices get to be Justices. The political process sketches the broad outlines of major doctrinal changes; newly appointed Justices merely work out the details.

In fact, the Justices are a force for stability in such changes. Lifetenured holdovers from earlier administrations resist change and slow it down. Without judicial review, Roosevelt's view of the Constitution, or Nixon's, or Reagan's, would have been implemented much more quickly. Newly appointed Justices sometimes turn on those who appointed them. Even Justices who implement the changes they were appointed to implement may moderate the pace or magnitude of change. It took twenty years

50. P. 11.

51. Ackerman, supra note 32 , at 510-15. 
of Republican appointments to the Court to produce the apparent new majority. We can argue whether this drag on the political branches is good or bad. But it refutes Nagel's claim that judges are the engine of change and not a source of doctrinal stability.

\section{B. Judicial Review and a General System of Free Speech}

Nagel's chapter on free speech applies and extends his general argument. He considers free speech not as an individual right, but only as a structural guarantee of democratic rule. He argues that judicial protection of free speech in individual cases is not necessary to maintain a general system of free speech, and may even be harmful. Judicial protection is not necessary because the political branches have always ended our worst periods of suppression-the Alien and Sedition Acts, the Red Scare after World War I, McGarthyism, wartime censorship-without much help from the judiciary. ${ }^{\mathbf{6 2}}$ Judicial protection may be harmful, because frequent judicial protection of the least attractive forms of speech may discredit the idea of free speech in the public mind..$^{53}$

Again, he disregards counterexamples. He says that the Supreme Court did not protect those who protested the War in Vietnam until 1968, when the war was already unpopular. ${ }^{54} \mathrm{He}$ is just wrong about the dates; the first decision protecting protest against the war came in $1966,{ }^{55}$ and the decisions protecting draft resisters began in $1965 .{ }^{.66}$ More important, the Vietnam protesters operated under shelter of the Court's decisions protecting civil rights protesters, ${ }^{67}$ and under earlier decisions protecting political extremists, ${ }^{58}$ religious proselytizers ${ }^{69}$ and labor organizers. ${ }^{60}$ These decisions made it unnecessary to decide a Vietnam protest case as such.

52. Pp. 36-37.

53. P. 39.

54. P. 57 \& n.164.

55. See Bond v. Floyd, 385 U.S. 116 (1966) (holding that Georgia legislature could not refuse to seat member who opposed war and draft).

56. See Oestereich v. Selective Serv. Sys. Local Bd. No. 11, 393 U.S. 233 (1968) (authorizing preinduction judicial review where local draft board denied exemption as punishment for protesting draft); United States v. Seeger, 380 U.S. 163 (1965) (effectively reading theism requirement out of exemption for conscientious objectors). My colleague Michacl Tigar, who litigated many Vietnam-era draft cases and was Editor-in-Chief of the Selective Service Law Reporter, agrees that 1969 was a turning point in the Supreme Court's willingness to scrutinize selective service decisions. But he attributes this change to judicial loss of confidence in local draft boards, and he believes it began somewhat earlier in the lower courts. Judges lost confidence when they began to encounter cases in sufficient numbers to become familiar with the actual administration of the selective service law. Cases did not begin to arise in large numbers until the war became unpopular. Thus, his explanation coincides chronologically with Nagel's. To distinguish the two explanations, Tigar relies on trial court decisions that were unpopular in their local communities, such as the acquittal of Cesar Chavez' son by a conservative district judge in Fresno, California. Conversation with Professor Michael Tigar (Nov. $15,1989)$. For further evidence supporting his loss of confidence thesis, see Oestereich: "We deal with conduct of a local Board that is basically lawless." 393 U.S. at 237.

57. See Brown v. Louisiana, 383 U.S. 131 (1966); Cox v. Louisiana, 379 U.S. 536 (1965); Edwards v. South Carolina, 372 U.S. 229 (1963).

58. See Terminiello v. City of Chicago, 337 U.S. 1 (1949); Schneider v. New Jersey, 30 S U.S. 
The right of political protest-the marches, rallies, vigils, sit-ins, Freedom Rides, and all the rest-was as critical to the civil rights movement as the desegregation decisions were. ${ }^{\mathbf{6 1}}$ Perhaps Nagel would say that civil rights protests would have succeeded even without judicial protection. Perhaps so; there were heroes and heroines in those days, willing to brave jail, chain gangs, police dogs, fire hoses, and even death for their cause. Maybe they would have persisted to victory even if the courts had denied them all constitutional protection and sided with the police dogs. Maybe they did not need all the lawyers they struggled to pay, or the Justice Department lawyers who supported them, or the Federal judges who defied ostracism and death threats. ${ }^{62}$ More likely, the protestors would have been worn down and defeated without judicial support. Certainly their organizations would have been bankrupted. ${ }^{83}$

There is no way to know whether the civil rights movement would have succeeded without judicial support. What is clear is that the movement thought it needed judicial support. The movement appears to have depended in substantial part on the kind of judicial activity Nagel most despises: on the repeated daily enforcement of constitutional principles in case after case, getting people out of jail, saving assets from seizure, protecting the right to raise funds and thus to keep the struggle going. I do not know what Nagel might have said about these cases. He ignores the civil rights protests and the decisions that protected them.

A partial exception is his casual treatment of New York Times $v$. Sullivan. ${ }^{64} \mathrm{He}$ twice offers the case as a bad example. ${ }^{66}$ His sarcastic initial description of the case implies that it is a usurpation: "For most of our history, reasonably vigorous public debate somehow coexisted with traditional defamation rules, but in 1964 it was discovered that the first amendment required significant alterations in these rules in order to foster vigorous public debate."186

$147(1939)$.

59. Ser Fowler v. Rhode Island, 345 U.S. 67 (1953); Niemotko v. Maryland, 340 U.S. 268 (1951); Kunz v. New York, 340 U.S. 290 (1951); Murdock v. Pennsylvania, 319 U.S. 105 (1943); Martin v. City of Struthers, 319 U.S. 141 (1943); Largent v. Texas, 318 U.S. 418 (1943); Cantwell v. Connecticut, 310 U.S. 296 (1940); Lovell v. City of Griffin, 303 U.S. 444 (1938).

60. Ser Thornhill v. Alabama, 310 U.S. 88 (1940); Hague v. Committee for Indus. Org., 307 U.S, 496 (1939).

61. This paragraph reflects on the history of the movement as told in T. Branch, Parting ThE Waters: AMerica in the King Years 1954-63 (1988), and in Kennedy, Martin Luther King's Cinslilution: A Ligal Histony of the Montgomery Bus Boycoll, 98 YALE L.J. 999 (1989). For an additional account, see H. Kalven, The Negro and the First Amendment (1965).

62. On the Federal judges, see J. Bass, Unlikely Heroes (1981); J. Peltason, Fifty-Eight LONELY MEN (1961). For an account of the death threats (and one attempt), see J. BASs, supra, at 79.

63. Se NAACP v. Claiborne Hardware Co., 458 U.S. 886 (1982) (reversing $\$ 1.25$ million judgment against NAACP); Henry v. First Nat'l Bank, 595 F.2d 291 (5th Cir. 1979) (enjoining enforcement of state court judgment against NAACP), cert. denied, 444 U.S. 1074 (1980).

64. 376 U.S. 254 (1964).

65. Pp. 10, 37.

66. P. 10. 
The Court discovered this in 1964 because Alabama officials discovered in 1960 that traditional defamation rules could be used to destroy a political movement. When Sullivan was decided, there were $\$ 5.6$ million worth of defamation claims pending in Alabama against the New York Times, and $\$ 1.7$ million against CBS. ${ }^{67}$ Recall that these claims were in 1964 dollars. In the first two cases to go to trial, juries had awarded the full amount claimed..$^{68}$ Many of these suits also named as defendants individual leaders of the civil rights movement. Seizure of the property of individual defendants so discouraged or intimidated some leaders of the Southern Christian Leadership Conference that they left Alabama and accepted jobs in the North. ${ }^{89}$ The devastating threat of the defamation judgments is a running theme in the history of the SCLC, ${ }^{70}$ but Nagel sees no First Amendment problem.

$\mathrm{He}$ is similarly insensitive about the patronage cases, ${ }^{71}$ which he also seems to see as usurpations with no real relationship to free speech and democratic rule. ${ }^{72}$ Nagel did not live in Chicago under the Daley machine. I am confident that he has never worked a precinct by himself while half a dozen employees of the city and of city contractors were paid with public funds to work it for the other side. He has not experienced the hopelessness of contesting elections in such a regime.

Judicial restrictions on patronage brought democracy to Chicago, replacing a one-party system in which all conflicts were resolved by secret deliberations among the ward committeepersons who ran the party. (In Chicago they were called committeemen, and in my time there, they were always men.) Plaintiffs ${ }^{73}$ and defendants ${ }^{74}$ agree that the patronage case broke up the machine and made it possible to hold competitive elections in Chicago. Once again, this impact depended on the kind of continued judicial activity that Nagel most despises. Patronage litigation in Chicago was

67. 376 U.S. at 295 (Black, J., concurring).

68. Id. at 294 .

69. See T. BRANCH, supra note 61 , at 580 .

70. See id. at 289, 295-96, 312, 370-71, 382, 391, 515, 579-82, 590, 694.

71. See Branti v. Finkel, 445 U.S. 507 (1980); Elrod v. Burns, 427 U.S. 347 (1976); Shakman v. Democratic Org., 533 F.2d 344 (7th Cir.), cert. denied, 429 U.S. 858 (1976); Illinois State Employee's Union v. Lewis, 473 F.2d 561 (7th Cir. 1972); Shakman v. Democratic Org., 435 F.2d 267 (7th Cir. 1970), cert. denied, 402 U.S. 909 (1971). I should disclose that many years ago, I played a very minor role in the Shakman litigation as a student associate at a Chicago law firm that represented plaintiffs.

72. Pp. 10, 37. For the contrary view that the patronage cases should be understood as concerned only with democratic rule, see Comment, Patronage and the First Amendment: A Structural Approach, 56 U. CHI. L. Rev. 1369 (1989).

73. See Johnson, Successful Reform Litigation: The Shakman Patronage Case, 64 CHI.-Kent L. REV. 479, 481-83, 486-88, 493-94 (1988).

74. See Keane, Tom Keane on Life After Daley, Chicago LAwyer, Apr. 1982, at 3. Keane, perhaps the second most powerful figure in the machine under the first Mayor Daley, wrote that the machine "is dying," and "the thing that is killing it is the Shakman decree." Id. at 4. "As long as it is enforced by federal courts, no one is ever again going to put together a powerful political organization in Chicago." Id. He notes that the organization began to lose down ballot races after the decree and before the death of Mayor Daley. Id. at 3. 
not a one-time pronouncement of constitutional values, nor a series of individual suits by discharged workers. With Shakman v. Democratic Organization, voters and candidates obtained a highly publicized structural injunction regulating public employment in Chicago. A public employee penalized for neglecting his precinct work did not have to know that he might have a claim, find a lawyer who would take his case on a contingent fee, and file an independent lawsuit that would take months or years to come to trial. Rather, such an employee could go to the Shakman lawyers and file a contempt citation that would be set for hearing in days or weeks. The same point is illustrated by the later opinion holding patronage hiring unconstitutional. ${ }^{75}$ This opinion had little impact until it was enforced with a detailed implementation decree. ${ }^{76}$

The first decade of democracy in Chicago has been messy. One-party states may be more efficient than democracies, especially for those on the inside of the party organization. The change from patronage to civil service may create a bureaucracy that is unresponsive to elected officials. ${ }^{77}$ We could debate whether that is worse than elected officials unresponsive to the voters, or whether courts should choose between these evils. But Nagel ignores reality when he asserts that patronage had nothing to do with a system of free speech and democratic government.

Nagel's failure to understand the patronage cases relates to his argument about the relative propensities of judges and politicians to protect free speech. He says that judges in their highly controlled courtrooms have no experience that would enable them to understand the value of free speech, while politicians engage in free speech every day. ${ }^{78} \mathrm{He}$ follows up by noting the disgraceful frequency with which judges try to suppress speakers whose public criticism hinders judicial functions. ${ }^{79}$

Once again he misses the central point. In all of his examples, a judge is suppressing speech that interferes with that judge's goals. Politicians have a similar tendency to suppress speech that interferes with their goals. Their most important goal is their own re-election. Thus, the great political temptation to censorship is protection of incumbents and their policies. Regulation of campaign finance always tends in that direction, and many of the Supreme Court's famous free speech cases-most obviously the protest cases and the national security cases-involved speech that was thought to hinder government policy. Perhaps the classic example of systemic incumbent protection is Huey Long's discriminatory tax on opposi-

75. Shakman v. Democratic Org., 481 F. Supp. 1315 (N.D. Ill. 1979), vacaled in part sub nom. Shakman v. Dunne, 829 F.2d 1387 (7th Cir. 1987), cert. denied, 108 S. Ct. 1026 (1988).

76. Shakman v. Democratic Org., 569 F. Supp. 177 (N.D. I1l. 1983); see Freedman, Doing Battle with the Patronage Army: Politics, Courts, and Personnel Administration in Chicago, 48 PuB. ADMIN. REv. 847, 850 (1988).

77. Sep id. at $856-57$.

78. Pp. 54-55.

79. P. 55 
tion newspapers, struck down by a unanimous Court ${ }^{80}$-one more example that Nagel neglects to mention. Judicial enforcement of free speech rights can be a check on incumbent protection, even if we need a different check on judges' own tendency to self-protection.

\section{G. Individual Rights}

One other striking aspect of Nagel's argument is his indifference to individual rights. He appears to assume, without saying so explicitly, that the majority is entitled to get its way, and that the resulting costs to individuals are no concern of constitutional law.

He complains in Chapter 4 that courts and commentators are too concerned about individual rights and not concerned enough about constitutional structure. But the principal point of this chapter is that federalism and separation of powers are underprotected. This alone does not necessarily imply that individual rights deserve little or no protection.

The clearest example of his attitude toward individual rights is in Chapter 3, on free speech. He considers free speech law exclusively in terms of preserving a general system of free speech. He ignores the harm to individual victims of censorship and retaliation, except to note in passing-at the very end of the chapter-that protecting individual victims might be a different rationale for free speech law. ${ }^{\mathbf{8 1}}$ It is not a rationale he investigates. He thinks he has written an evaluation of judicial review in free speech cases without considering the interests of individual speakers.

Nagel also makes an original intent argument against the importance of individual rights. $\mathrm{He}$ is surely right that our generation relies more than the founders did on express individual rights and judicial review, and less on separation of powers and federalism. But the difference lies in emphasis and degree. Nagel claims a much sharper difference, and to prove his point, he relies on mischaracterization and misquotation.

He argues that the framers saw federalism and separation of powers as "the great protection of the individual, not the 'parchment barriers' that were later (and with modest expectations) added to the document." ${ }^{\text {'82 }}$ The accompanying footnote claims that "[w]hen Madison proposed the Bill of Rights to Congress, its importance for preserving freedom was not emphasized." 83 These claims are simply false.

The phrase "parchment barriers" appears in The Federalist No. 48, but it does not refer to the Bill of Rights. Instead, it refers to separation

80. Grosjean v. American Press Co., 297 U.S. 233 (1936). For an account of the political significance of Grosjean, see L. Powe, The Fourth Estate and the Constitution ch. 7 (forthcoming 1990).

81. P. 59.

82. P. 65.

83. P. 188 n.34. 
of powers provisions of the form then found in many state constitutions. ${ }^{84}$ These were merely "parchment barriers"8s because they lacked independent enforcement mechanisms. These provisions announced limits to legislative power, but they did not give the other branches power to enforce these limits. Consequently, the legislatures regularly exceeded their limits. ${ }^{86}$ The solution was to provide for perpetual enforcement-to give "to those who administer each department the necessary constitutional means and personal motives to resist encroachments of the others." ${ }^{87}$ The defect of "parchment barriers" was precisely the defect of Nagel's proposal for constitutional rights without judicial enforcement.

A similar phrase, "paper barriers," appears in Madison's great speech of June 8,1789 , introducing the Bill of Rights to the First Congress. ${ }^{88}$ Once again, Madison was setting up the argument to refute it. $\mathrm{He}$ conceded that some state bills of rights had been violated, ${ }^{89}$ but he said that a Federal Bill of Rights would be enforced by an independent judiciary ${ }^{90}$ It

84. "Will it be sufficient to mark, with precision, the boundaries of these departments in the constitution of the government, and to trust to these parchment barriers against the encroaching spirit of power?" The Federalist No. 48, at 308 (J. Madison) (C. Rossiter ed. 1961).

85. Id.

86.

This is the security which appears to have been principally relied on by the compilers of most of the American constitutions. But experience assures us that the efficacy of the provision has been greatly overrated; and that some more adequate defense is indispensably necessary for the more feeble against the more powerful members of the government. The legislative department is everywhere extending the sphere of its activity and drawing all power into its impetuous vortex.

Id. at 308-09.

87. The Federalist No. 51, at 321-22 (J. Madison) (C. Rossiter ed. 1961). The Federalist No. 48 analyzes the problem to which the more famous No. 51 proposes the solution. The intervening papers, Nos. 49 and 50, consider and reject two other proposed solutions.

88.

It may be thought that all paper barriers against the power of the community are too weak to be worthy of attention. I am sensible they are not so strong as to satisfy gentlemen of every description who have seen and examined thoroughly the texture of such a defence; yet, as they have a tendency to impress some degree of respect for them, to establish the public opinion in their favor, and rouse the attention of the whole community, it may be one means to control the majority from those acts to which they might be otherwise inclined.

1 Annals of Cong. 456 (J. Gales ed. 1834) (remarks of James Madison) (June 8, 1789). Pagination is different in other printings of the Annals. 89.

It has been said, that it is unnecessary to load the constitution with this provision, because it was not found effectual in the constitution of the particular States. It is true, there are a (sic) few particular States in which some of the most valuable articles have not, at one time or other, been violated; but it does not follow but they may have, to a certain degree, a salutary effect against the abuse of power.

IN. at $456-57$.

90.

If they [the rights in the Bill of Rights] are incorporated into the constitution, independent tribunals of justice will consider themselves in a peculiar manner the guardians of those rights; they will be an impenetrable bulwark against every assumption of power in the legislative or executive; they will be naturally led to resist every encroachment upon rights expressly stipulated for in the constitution by the declaration of rights.

II. at 457 . 
was judicial review that would turn "paper barriers" into "an impenetrable bulwark."91

I have already said enough to show that Nagel flatly mischaracterizes Madison. But the mischaracterization goes much further. Indeed, the whole modern theory of judicial review in individual liberty cases is encapsulated in Madison's June 8 speech. The need for a Bill of Rights even in a government of limited powers, ${ }^{92}$ the risk that a majority of the community would oppress a minority, ${ }^{93}$ the importance of judicial review, ${ }^{94}$ and the need to protect unenumerated rights ${ }^{95}$ - it's all there in ten pages of the Annals of Congress. ${ }^{96}$ Like many other judicial conservatives, Nagel appeals simultaneously to the virtues of original intent and popular democracy. But he cannot have it both ways, because the original intent

91. Id.

92. "[I]f all power is subject to abuse, .... then it is possible the abuse of the powers of the General Government may be guarded against in a more secure manner than is now done . . . ." Id. at $449-50$.

It is true, the powers of the General Government are circumscribed, they are directed to particular objects; but even if Government keeps within those limits, it has certain discretionary powers with respect to the means . . . [For example,] the General Government has a right to pass all laws which shall be necessary to collect its revenue; the means for enforcing the collection are within the direction of the Legislature: may not general warrants be considered necessary for this purpose, as well as for some purposes which it was supposed at the framing of their constitutions the State Governments had in view? If there was reason for restraining the State Governments from exercising this power, there is like reason for restraining the Federal Government.

Id. at $455-56$.

93.

[State bills of rights are directed] sometimes against the abuse of the executive power, sometimes against the legislative, and, in some cases, against the community itself; or, in other words, against the majority in favor of the minority.

In our Government it is, perhaps, less necessary to guard against the abuse in the executive department than any other; because it is not the stronger branch of the system, but the weaker: It therefore must be levelled against the legislative, for it is the most powerful, and most likely to be abused, because it is under the least control. Hence, so far as a declaration of rights can tend to prevent the exercise of undue power, it cannot be doubted but such declaration is proper. But I confess that I do conceive, that in a Government modified like this of the United States, the great danger lies rather in the abuse of the community than in the legislative body. The prescriptions in favor of liberty ought to be levelled against that quarter where the greatest danger lies, namely, that which possesses the highest prerogative of power. But this is not found in either the executive or legislative departments of Government, but in the body of the people, operating by the majority against the minority.

Id. at $454-55$.

94. Id. at 457 (quoted supra note 90).

95.

It has been objected also against a bill of rights, that, by enumerating particular exceptions to the grant of power, it would disparage those rights which were not placed in that enumeration; and it might follow, by implication, that those rights which were not singled out, were intended to be assigned into the hands of the General Government, and were consequently insecure. This is one of the most plausible arguments $I$ have ever heard urged against the admission of a bill of rights into this system; but, I conceive, that it may be guarded against. I have attempted it, as gentlemen may see by turning to the last clause of the fourth resolution.

Id. at 456. The last clause of the fourth resolution, $i d$. at 452 , was an early draft of the Ninth Amendment.

96. Madison also argued that the states would enforce the Bill of Rights. Id. at 457. This expectation is not obsolete, but it is of limited utility in the wake of the Givil War and the Reconstruction Amendments. 
embraced only limited democracy. The founders viewed legislatures as a serious threat to liberty, and at least one, Madison, saw further and realized that the ultimate threat came from the majority of the people.

Nagel's account of original intent also distorts the larger political fight over ratification. I know of no one who claims that the Constitution could have been ratified without the promise of a Bill of Rights. Whatever the delegates at Philadelphia might have thought, a large part of the American people demanded and got a Bill of Rights. The Bill of Rights was an essential part of the original bargain; the argument that it was unnecessary did not prevail.

Attention to the rights of individuals strikes at the heart of Nagel's position. If one is indifferent to the rights of individual victims, then one will be puzzled by judicial enforcement of individual rights. But if one believes that the Constitution guarantees individual rights-which seems clear from the text-and if one believes that each individual is important, then vigorous judicial enforcement of those rights will not be puzzling. ${ }^{97}$

Attention to individual rights also has more specific implications for Nagel's argument. The number of individuals whose rights can be suppressed without threatening the general system of free speech may be quite large, especially if the victims are an identifiable category so that the citizenry at large does not fear that suppression will spread to it. It may even be that the political system responds best to the most severe outbreaks of suppression, like McCarthyism. Once it began to appear that few public figures and few government employees were safe, a powerful constituency was mobilized to fight McCarthy. In sharp contrast, the political branches did not respond to defend the Jehovah's Witnesses, who were systematically restricted, prosecuted, and harassed. Only a long series of Supreme Court decisions ended American persecution of Jehovah's Witnesses. ${ }^{88}$ Thus, Nagel's comfortable reliance on the political branches may be a function of his disregard for the rights of individuals.

\section{The Merits of Judicial Review and the Meaning of the Constitution}

\section{Nagel's Criteria for Evaluating Judicial Review}

Much of Nagel's argument against active judicial review consists of examples of cases where judicial review worked badly or where the other branches did better. Much of my response consists of examples where judicial review worked well or where the other branches did even worse.

97. For the argument that individualism is a unifying constitutional value, see Laycock, Taking Constitutons Seriously: A Theory of Judicial Review (Book Review), 59 TEx. L. Rev. 343, 371-76 (1981)

98. For a summary of these cases, see Laycock, A Sur'ey of Religious Liberty in the United States, 47 Ohio ST. L.J. 409, 419-20 (1986). For an account of the private harassment of Witnesses, sec P. Irons, The Courage of Their Convictions 22-35 (1988). 
Nagel's examples alone are misleading; my examples alone would be equally misleading. The reality includes both sets of examples. Nagel does well to remind the more naive proponents of judicial review that judges are not always the friends of liberty, and that the other two branches are not always the enemy. What conclusions follow when both sets of examples are considered together?

The justification for active judicial review does not depend on any claim that judges are always right, or even that on average they are right more often than the political branches. The justification is that judicial review gives claims of constitutional right one more chance to be heard. Constitutional claims can be presented to the legislature and the executive like any other legal or political claim. But in addition, constitutional claims can be presented to the courts, and the courts are obliged to listen. The courts are reasonably insulated from short-term political pressures, although hardly insulated at all from long-term political changes.

The courts may or may not be any more sympathetic than the other branches, but they ensure that constitutional claims will at least get a hearing, and they give the constitutional claim one more chance to prevail. And in this last chance, the sources of political rigidity in judicial review also yield important advantages. For minorities and isolated individuals, it is a decided advantage to have one branch that is obliged to hear their claims, to render public judgment, to state principled reasons for decision, and to treat like cases alike. ${ }^{99}$

This extra chance will not always be needed, and it will not always be efficacious. Sometimes Congress will be the best protector of liberty, as during Reconstruction, or in the Equal Access Act, ${ }^{100}$ which protects student free speech from judicial content discrimination, or in the statute allowing military officers to wear yarmulkes. ${ }^{101}$

Sometimes the executive will be a powerful protector of liberty, as in the Civil Rights Division's litigation in the sixties, ${ }^{102}$ or in Truman's desegregation of the military, ${ }^{103}$ or-if you think he was right-in Jackson's veto of the Second Bank. ${ }^{104}$ I would add the Emancipation Proclamation

99. Cf. Delgado, Dunn, Brown, Lee \& Hubbert, Fairness and Fornality: Minimizing the Risk of Prejudice in Alternative Dispute Resolution, 1985 W Is. L. REv. 1359 (arguing that minorities are disadvantaged by informal dispute resolution).

100. 20 U.S.C. $\$ \$ 4071-4074$ (1988).

101. 10 U.S.C. $\$ 774$ (1988) (overruling result in Goldman v. Weinberger, 475 U.S. 503 (1986)).

102. See T. BRANCH, supra note 61 , passin. A detailed index identifies descriptions of the Justice Department's role under the following entries: "Doar, John," "Justice Department, U.S.," "Kennedy, Robert F.," "Marshall, Burke," and "White, Byron."

103. See Butler, Race Relations in the Military, in The Military: More than Just a Job? 115, 119 (C. Moskos \& F. Woad eds. 1988).

104. For a review of the Bank controversy, see P. Brest \& S. Levinson, Processes of Constitutional Decisionmaking 9-59 (2d ed. 1983). Jackson's veto message is excerpted in id. at 51-56; the entire message appears in 2 Messages and Papers of The Presidents 576-91 (J. Richardson ed. 1897). Jackson thought he was protecting the people from the dangers of concentrated wealth and concentrated Federal power. 
and Lincoln's prosecution of the Civil War, even though Lincoln repeatedly violated the Constitution in pursuit of larger goals. Lincoln and the Reconstruction Congresses accomplished a true revolution-a fundamental change in favor of liberty, achieved by force of arms because it could not be achieved within the voting rules created by the original Constitution. ${ }^{108}$ Revolutions by definition violate positive law; they must be legitimated by their moral rightness and by subsequent acceptance of their results. Like Washington's before him, Lincoln's revolution has been legitimated. ${ }^{108}$

Sometimes the Court will be the best protector of liberty, as in the Jehovah's Witness cases, the desegregation cases, the school prayer cases, the reapportionment cases, and the criminal procedure cases. Sometimes all three branches will collaborate in a constitutional violation, as in the nineteenth century persecution of the Mormons, ${ }^{107}$ or the oppression of blacks for three-quarters of a century after the end of Reconstruction.

Nagel's argument against judicial review relies heavily on the history of judicial errors. In considering such an argument, it is essential to distinguish two kinds of errors. Judges may err by not enforcing liberties that the Constitution guarantees, or they may err by enforcing supposed liberties that the Constitution does not guarantee. Both types of error are inevitable, but only the second type supports an argument against judicial review.

In the first type of error, where the judges fail to protect a constitutional right, they have failed to perform their function. That is bad for the constitutional system, and bad for liberty. But this kind of judicial error does not make us worse off than we would have been without judicial review. Judicial failures to protect liberty, judicial enforcement of oppression by the other branches, even doctrinal fluctuations between protecting constitutional rights and not protecting them-none of these is an argument against active judicial review. As long as the judges enforce constitutional rights some of the time, they are doing some good, and that good is not offset by other instances in which the judges fail to do other good.

A serious argument against judicial review arises only from the second

105. For a demonstration that the Reconstruction Amendments cannot be legitimated by the voting rules in Article $V$ of the Constitution, see Ackerman, supra note 32, at 500-07. Ackerman does not characterize the amendments as revolutionary.

106. For the difficulties of deciding whether Lincoln was loyal to the pre-1865 Constitution, see S. Levinson, Constirutronal. Faith 139-42 (1988). For the argument that Lincoln was one of the "principal architects of our constitutive tradition," see Nichol, Children of Distant Fathers: Skttching an Ethos of Constitutional Liberty, 1985 WIs. L. REv. 1305, 1323-24, 1328-33.

107. See Late Corp. of the Church of Jesus Christ of Latter-Day Saints v. United States, 136 U.S. 1 (1890) (upholding confiscation of church property); Davis v. Beason, 133 U.S. 333 (1890) (upholding religious test oath for voting); Reynolds v. United States, 98 U.S. 145 (1878) (affirming criminal conviction for polygamy). For a full history, see E. FIRMAGe \& R. MANGRUM, ZION IN THE Courts: A Legal History of the Church of Jesus Christ of Latter-day Saints, 1830-1900 (1988). 
type of error, where judges begin to enforce things that are not in the Constitution at all. The Lochner-era liberty of contract cases are an example, and the busing cases are an example from the other end of the political spectrum. ${ }^{108}$ In these cases, the courts inflicted high social costs on the basis of constitutional misinterpretations. In cases where that happens, we would be better off without judicial review. If we were debating a constitutional amendment to eliminate judicial review, these costs of judicial review would be weighed against the benefits.

If it were perfectly clear what the Constitution guarantees, we would not have judicial errors of either type. Indeed, we would not need an elaborate judicial procedure to apply the Constitution to individual cases. Because the Constitution is not perfectly clear, Americans will not be able to agree on a single list of cases in which the courts did harm by enforcing rights not to be found in the Constitution.

\section{Nagel's Rules of Constitutional Interpretation}

We come therefore to the heart of the problem: What does the Constitution mean? Nagel thinks it self-evident that the individual liberty provisions of the Constitution mean almost nothing. He finds most constitutional interpretation "exceedingly implausible," "downright implausible," and "magical or superstitious." ${ }^{109} \mathrm{He}$ believes "that the Constitution either does not bear at all, or bears only in complex and indeterminate ways, on most specific public issues." ${ }^{110} \mathrm{He}$ implies that it is unsophisticated-naive or just foolish-to find the Court's interpretations plausible. ${ }^{111}$ $\mathrm{He}$ offers no argument to support these claims.

This is not the place to carefully explore the meaning of the Constitution. I will say here that I find Nagel's assertions not merely implausible, but almost incomprehensible. I understand disagreement about constitutional interpretation at the margins, even on important issues. But I do not understand the claim that almost nothing is unconstitutional.

The Constitution states principles in sweeping terms. Each of these principles seems on its face to apply to a broad range of cases. Whatever else one says about the Supreme Court's free speech and press cases, they are nearly always cases in which some unit of government has restricted or penalized someone's speech, or someone's use of a printing press, or someone's use of a modern analogue of the printing press. These cases fall

108. Any contemporary example of excess will inevitably be more controversial than an old example. I believe that the busing cases are not constitutionally required, because they seek to achieve a new status quo that would never have existed even if the Constitution had not been violated. For this view of remedies as designed to restore victims to their rightful position, and the contrasting view that equity courts have a general commission to do good in the wake of a violation of law, see D. LAYCOCK, MOdern American Remedies: Cases and Materials 234-81 (1985).

109. Pp. 3-4.

110. P. 4.

111. P. 4. 
naturally within the broad principles stated in the speech and press clauses. Similarly, whatever else one says about the Supreme Court's equal protection cases, they are nearly always cases in which some unit of government has applied one law to one group of persons, and a different, unequal law to another group of persons who are in some sense similarly situated. These cases fall naturally within the broad principle stated in the equal protection clause. And so on. To claim that nothing in the Constitution informs the great bulk of constitutional cases requires an invincible hostility to the constitutional text. Even very conservative judges recognize that the Constitution contains principles that potentially apply to modern legislation. ${ }^{112}$ Only Lino Graglia exceeds the extremism of Nagel's claim that almost nothing is unconstitutional. ${ }^{113}$

The claim that the Constitution says nothing about most constitutional controversies necessarily entails one or both of the following claims:

1) The text of the Constitution does not count. Constitutional meaning is to be found only in extra-constitutional sources, such as the unratified writings, speeches, and thoughts of the founders.

2) Broad statements of principle do not count. The Constitution would apply to specific disputes only if the founders had anticipated each dispute.

Nagel does not say that the text does not count. But he does appear to say that the text alone does not count. He would permit the judiciary to invalidate the acts of other government institutions only when those acts are "emphatically inconsistent with constitutional theory, text, and public understanding as expressed in prolonged practice."114 In another formulation of this point, he requires inconsistency with "the clear sense and history of the Constitution and . . . apparent public understandings." 115 So the constitutional text does not count unless it is confirmed by public understanding, and either constitutional theory or history, or perhaps both.

His demand for "public understanding" makes the constitutional rights

112. S't, $\ell^{\prime} \cdot g$., Texas v. Johnson, 109 S. Ct. 2533 (1989) (Scalia joined majority opinion reversing cruminal conviction for flag desecration); National Treasury Employees Union v. Von Raab, $109 \mathrm{~S}$. C1. 1384, 1398 (1989) (Scalia, J., dissenting) (voting to invalidate requirement that Treasury employees submit to urinalysis); American Booksellers Ass'n v. Hudnut, 771 F.2d 323 (7th Cir. 1985) (Easterbrook, J.) (striking down pornography ordinance), affd mem., 475 U.S. 1001 (1986); Ollman v. Evans, 750 F.2d 970, 993 (D.C. Cir. 1984) (Bork, J., concurring) (protecting expressions of opinion from liability for defamation), cert. denied, 471 U.S. 1127 (1985).

113. Ste, t.g., Graglia, Constitutional Mysticism: The Aspirational Defense of Judicial Retiew (Book Review), 98 Harv. L. Rev. 1331, 1344 \& n.26 (1985) ("If judicial review were in fact limited to merely enforcing the restrictions of the Constitution, there would be so few occasions for its exercise that it would be a subject of little controversy or even interest. . . . An example of a plainly unconstitutional statute would be difficult to find in a standard constitutional law casebook, except for the debtor relief law involved in Home Bldg. \& Loan Ass'n v. Blaisdell.") (citation omitted).

114. P. 3.

115. P. 24. 
of minorities and isolated individuals hostage to the constitutional understanding of a hypothetical majority. He would make judicial protection available only when it is not needed. He wholly rejects the Madisonian effort to protect the minority from the majority by constitutional law. ${ }^{116}$

His apparent treatment of history, theory, and public understanding as equal in authority to the text ignores what was ratified. Representatives of the American people once voted on the constitutional text. They did not vote on anyone's theory, or on anyone's account of history, or on future public understanding. ${ }^{117}$ Of course we must read the text in historical context, and we must try to identify the theory or theories that unify the text. But only the text was ratified, and it is the ultimate source of constitutional law.

At another point, Nagel suggests that broad statements of principle in the Constitution do not count, because they are "so general and cryptic." 118 This too is part of the mindset that enables one to claim that the Constitution forbids almost nothing. It assumes that the founders were either naive or disingenuous-either fool enough to think that broad statements of principle would matter, or knavish enough to include such statements knowing they would not matter. I will leave it to original intent theorists to work out the competing implications of a fool theory and a knave theory.

If instead we take seriously the sweeping principles stated in the constitutional text, they seem to both protect and forbid a great number of things. But few of those things are specifically mentioned. The Constitution does not expressly mention seditious libel, political debate, religious proselytizing, great literature, pulp novels, newspaper editorials, sports reporting, gossip columns, small talk, political cartoons, drive-in movie theaters, or television. Instead, it refers generically to "freedom of speech or of the press." It does not expressly mention the death penalty for speech, or punitive damages, or presumed damages, or damages for emotional distress, or firing government employees, or suspending students from school, or excluding preachers from parks, or knocking down protesters with fire hoses and police dogs. Instead, it refers generically to "abridging" the freedom of speech.

To insist that every application of the Constitution be stated in the constitutional text-and presumably also in the legislative history and in the public understanding-is to make constitutionalism impossible. Constitutional protections of liberty are possible only if they are stated as broad

116. See supra note 93 .

117. I address the choice between text and extrinsic evidence of original intent in D. Laycock, Originalism, Text, and Intent (1990) (unpublished manuscript on file with author).

118. P. 126. 
principles. ${ }^{110}$ To say that such sweeping principles have no application is to deny the possibility of constitutional meaning.

\section{The Special Gase of Federalism}

Chapter 4 of Nagel's book is about federalism. It fits oddly with the rest of the book, because its principal claim is that the Court has not been active enough in protecting federalism. But there is no reason to think that federalism decisions are exempt from Nagel's general critique of judicial review. If judicial enforcement can only make a mess of individual liberties, then surely it can only make a mess of federalism. What Nagel would apparently like is an occasional symbolic reaffirmation of federalism, with no follow up litigation demanding case-by-case enforcement. But as he recognizes, that is an impossible dream. ${ }^{\mathbf{1 2 0}}$

Much of the chapter is devoted to an elaborate defense of National League of Cities $v$. Usery. ${ }^{121}$ This is well worth reading, especially for those scholars who claim to find the Court's opinion comprehensible only as an implicit declaration of a constitutional right to welfare. ${ }^{\mathbf{1 2 2}}$ It is not difficult to understand the state's interest in controlling the relationship between itself and its employees, and Nagel elaborates the point with more clarity and force than the Court did. He exposes the methodological inconsistencies of scholars who insist on expansive interpretations of individual rights provisions and crabbed readings of federalism provisions. ${ }^{123}$

It is less clear to me that this state interest is constitutionally protected. Nothing in the constitutional text immunizes states from Federal regulation of interstate commerce. ${ }^{124}$ Rather, the Constitution protects the states by limiting the powers of the Federal Government. The question is whether state and local government employment is a transaction in interstate commerce. State and local government employees are now $12.7 \%$ of civilian employment, ${ }^{125}$ down from $13.9 \%$ when National League of Cities was decided. ${ }^{128}$ Even if there can still be small pockets of isolated

119. I mean to assert only that the Constitution itself must be stated in terms of broad principles. This is a corollary of its brevity, its permanence, and its functions. I do not speak to the distinct issue of how broadly or narrowly courts should formulate legal doctrine explicating the Constitution. On the latter issue, see Schauer, Harry Kalten and the Perils of Particularism (Book Review), $56 \mathrm{U}$. CHI. L. Rev. 397 (1989).

120. P. 81 .

121. 426 U.S. 833 (1976).

122. Michelman, States' Rights and States' Roles: Permutations of "Sot'ereignty" in National League of Cities v. Usery, 86 YALE L.J. 1165 (1977); Tribe, Unraveling National League of Cities: The New' Federalism and Affirnatize Rights to Essential Government Services, 90 Harv. L. Rev. 1065 (1977).

123. P. 64.

124. See Laycock, supra note 97 , at 366-67.

125. See Statistical Abstract of the United States, Table 479, at 293 (109th ed. 1989) $(13,913,000$ state and local government workers); $i d$. ., Table 626 , at 380 (109,597,000 persons employed in civilian non-institutional population age 16 and over).

126. The Tables cited supra note 125 show $12,054,000$ state and local government employees in 1975 out of $85,846,000$ employed persons in the civilian non-institutional population age 16 and over. 
workers whose conditions do not affect interstate commerce, National League of Cities was not such a case.

Nagel also seems to think that National League of Cities was consistent with public understanding of the role of state and local governments. ${ }^{\mathbf{1 2 7}}$ On this point, I am quite sure he is wrong. To the extent that the public knew about this controversy at all, the public was simply puzzled and angry that some American workers were denied the protections accorded to all other American workers. I am confident of that point from personal experience on an analogous issue. I have argued that the free exercise clause exempts churches from a wide range of labor regulation. ${ }^{128}$ The dominant response to that position-from committees of church representatives, from my students, and from other scholars-is that church workers are entitled to the same rights as other workers. I can sometimes persuade people to see the churches' interest in controlling the workforce that performs its religious mission, but the first reaction is always sympathy for the workers. I doubt that public understanding would be any different with respect to government workers.

Apart from overruling National League of Cities, one can hardly charge the present Supreme Court with inattention to federalism. It has created an elaborate set of substantive, jurisdictional, and procedural obstacles to lawsuits challenging illegal behavior of state and local officials. ${ }^{129}$ Most of this law has been created in the name of federalism. Nagel waves it aside on the ground that it is not expressly constitutional law. ${ }^{130} \mathrm{He}$ does not even mention the Court's expansive interpretation of the Eleventh Amendment, which is done in the name of the Constitution and goes far beyond anything arguably found in the constitutional text. ${ }^{131}$

Still, Nagel is right that the late twentieth century understanding of federalism is very different from the late eighteenth century understanding of federalism. He seems to blame this change on the judges. ${ }^{\mathbf{1 3 2}}$ Whether the judges caused it, or helped it, or merely acquiesced in it, it is common for commentators to imply that somehow a usurpation has occurred-that the shift to Federal power cannot be justified by any positivist theory of constitutional interpretation. ${ }^{\mathbf{1 3 3}}$

127. Pp. $80-81$.

128. Laycock, Towards a General Theory of the Religion Clauses: The Case of Church Labor Relations and the Right to Church Autonomy, 81 Cou.um. L. REv. 1373 (1981).

129. See generally 17 C. Wright, A. Miller \& E. Cooper, Federal Practice and ProceDURE $\$ \S 4221-37$ (1988) (Federal injunctions against state proceedings and Federal actions to restrain state officers); 17A C. Wright, A. Miller \& E. Cooper, Federal Practice and ProceDURE $\$ \$ 4241-4268.5$ (abstention doctrines, "Our Federalism," and habeas corpus).

130. P. 62.

131. See Marshall, Fighting the Words of the Eleventh Amendment, 102 Harv. L. REv. 1342 (1989).

132. P. 11.

133. See, e.g., Ackerman, supra note 32, at 457-58, 510-15 (rejecting as "myth" claim that New Deal policies were valid under Constitution as it existed prior to 1930's, and insisting that New Deal required implicit constitutional amendment). 
The claim that the Constitution does not authorize the current balance of state and Federal power has always seemed to me fundamentally wrong, in part for familiar reasons and in part for reasons that are often neglected. Before the Civil War, eleven of twelve constitutional amendments limited Federal power. Since the Civil War, nine of fourteen amendments expanded Federal power, ${ }^{134}$ and some of the expansions have been enormous.

The most familiar expansion of Federal power resulted from the Civil War and the Reconstruction Amendments. Nagel manages to write a chapter on federalism without mentioning either in his text! He does say in a footnote that the Fourteenth Amendment does not justify "losing sight of the framers' original scheme." ${ }^{\text {'3s }}$ Jefferson Davis could not have said it better. But the Reconstruction Amendments, enacted to the end that "these honored dead shall not have died in vain,"138 are not plausibly viewed as narrow technical changes that left intact "the framers' original scheme."

The second reason, familiar but less so, is the transportation and communication revolutions that forever changed the nature of interstate commerce. One could apply the Supreme Court's modern law of interstate commerce to the economy of 1787, and most commerce would be intrastate. Land transportation was prohibitively expensive; the cost of shipping goods thirty miles inland equaled the cost of shipping them to Europe. ${ }^{137}$ Consequently, the nation was divided into a large number of small local markets. Most commerce was contained within one of these markets, and prices in one market had little or no effect on prices in another. With the coming of the railroads, the local market was linked to national markets and lost control of its destiny. Local prosperity now depended on far away and uncontrollable developments. The change was sudden and dramatic; it required no legal fiction to see the effects. ${ }^{\mathbf{1 3 8}}$ When railroads or paved highways ran everywhere, the change was universal. No state or locality could manage its own economy and no commerce was beyond the reach of the commerce clause.

Voters increasingly chose to regulate this integrated national economy at the Federal level, especially after the Great Depression overwhelmed

134. I am counting amendments $13-19,24$, and 26 . Some of these were single issue amendments not part of any larger package-women's suffrage (Nineteenth Amendment), abolition of the poll tax (Twenty-Fourth Amendment), the eighteen year old vote (Twenty-Sixth Amendment), and prohibition (Eighteenth Amendment).

135. Pp. $188-89$ n.34.

136. A. Lincol.n, GetTysburg Address (1863).

137. See J. McPherson, Battle Cry of Freedom: The Givil War Era 11 (1988).

138. For a general history, see G. TAYlor, The Transportation Revolution, 1815-1860 (1951). For an account of what happened when the railroad came to a pioneer community in central Illinois, see J. Faragher, Sugar Creek: Life on the Illinois Prairie 178-80, 216-17, 221-22 (1986). 
the resources of state and local government. ${ }^{139}$ This choice of Federal regulation was authorized by the original constitutional text, and contrary Supreme Court decisions were properly viewed as obstructionist. The concept of intrastate commerce became obsolete, not because of judicial interpretation, but because of technological change.

The third reason for the growth of Federal power, almost wholly neglected by constitutional lawyers who hated the basic tax course, is the Sixteenth Amendment. The Sixteenth Amendment made available to the Federal Government a vast source of revenue previously denied to it. It authorized the federal government to take as large a share of the national income as it could persuade the voters to allow. This share turned out to be very large, especially after a little-known corporate financial officer invented the withholding tax. ${ }^{140}$

The Sixteenth Amendment was duly ratified by three-quarters of the states precisely because the people wanted a bigger Federal Government - because without a new revenue base, the Federal Government could not do what voters now expected it to do. The need for more revenue presupposes a need for more spending, which in turn implies a Hamiltonian understanding of the spending clause. ${ }^{141}$

As much as any other issue, and more than most, the federal tax power separated the founding Federalists and Anti-Federalists. One historian describes the Virginia Anti-Federalists as fearing Federal power, and especially the tax power, "almost to the point of paranoia." 142 In part to accommodate such fears, Federal powers of direct taxation were subjected to apportionment conditions so burdensome that the powers were rarely exercised. ${ }^{143}$ The Sixteenth Amendment changed all that. It has made possi-

139. On the exhaustion of state and local resources, see J. BuRns, ThE Workshop of DemocRacy 556-57 (1985); R. Caro, The Years of Lyndon Johnson: The Path To Power 241-52 (1982); C. Phillips, From the Crash to the Blitz, 1929-1939, at 33-54 (1969); A. Romasco, The Poverty of Abundance: Hoover, the Nation, and the Depression 152-72 (1965); A. Schlesinger, The Coming of The New Deal 261-81 (1959).

140. See D. Brinkley, WAshington Goes to WAR 216-19 (1988). For a scholarly account, see Jones, Class Tax to Mass Tax: The Role of Propaganda in the Expansion of the Income Tax: During World War II, 37 Buffalo L. REv. 685, 695-97 (1988).

141. Hamilton argued that the power to spend for the general welfare was not limited to the scope of the other grants of power in Article I. See A. Hamilton, Report on the Subject of Manufactures (1791), in 10 The Papers of Alexander Hamilton 302-04 (H. Syrett \& J. Cooke eds. 1966); see also United States v. Butler, 297 U.S. 1, 64-67 (1936) (adopting Hamilton's interpretation).

142. T. Curry, The First Freedoms: Church and State in America to the Passage of THE FIRST AMENDMENT 209 (1986). For predictions that the Federal tax power would oppress the people, monopolize the sources of revenue, and thus destroy the state governments, see $3 \mathrm{~J}$. ELLIOT, Debates on the Adoption of the Federal. Constitution 55-57 (reprint ed. 1987) (remarks of Patrick Henry); 2 id. at 337-39 (remarks of John Williams and Melancton Smith).

143. See F. McDonald, Novus Ordo Seclorum: The Intellectual Origins of the ConSTITUTION 264 (1985) (due to variations in wealth between states, requirement that direct taxes be apportioned by population "was so inequitable that, for practical purposes, it virtually denied Congress the power to levy direct taxes altogether."). Congress levied apportioned taxes on real estate and slaves once in 1798, for several years to finance the War of 1812 , and once (on real estate only) at the outbreak of the Civil War. The statutes are collected in Springer v. United States, 102 U.S. 586, 
ble all the vast growth of Federal Government in this century. The American Taxpayer's Association understood this best; it responded to the New Deal by urging the repeal of the Sixteenth Amendment. ${ }^{144}$

The Sixteenth Amendment worked as profound a change in American federalism as the Fourteenth. Yet it is not even mentioned in the leading constitutional law casebooks, ${ }^{145}$ and it gets only a passing mention in the leading treatise. ${ }^{146}$ Bruce Ackerman asks rhetorically, "What possible relevance does the enactment of the Income Tax Amendment . . . have on the continuing vitality of Plessy's interpretation of the Fourteenth Amendment?"147 His implicit answer is "none whatever." That answer seems reasonable until you learn that for Ackerman, what undermined Plessy" was "the New Deal's affirmation of activist government."148 The Sixteenth Amendment had everything do with the rise of an activist federal government, and the demand for activist Federal Government was part and parcel of the demand for activist government at all levels.

Direct election of Senators caused a fourth accretion to Federal power. When state legislatures elected United States Senators, and more to the point, when state legislatures re-elected or refused to re-elect United States Senators, one house of Congress was directly beholden to state legislatures. It is hard to imagine that a senator so elected could defy his legislature on a matter important to it. Direct election made it possible for the people to appeal directly to their Federal representatives without interference by their state legislatures, and for Federal representatives to appeal directly to the people without worrying as much about what state legislators might think. To the extent that expansion of Federal power might be limited by the institutional jealousy of state governments, the power of state governments was reduced.

It is hard to know the size of this effect, and I do not claim that it was large. The Amendment was debated on grounds of direct versus indirect democracy; legislative deadlocks and corruption in the choice of senators had become a scandal. ${ }^{149}$ The progressive demand for direct election was related to the progressive demand for more responsive and activist government, but federalism implications as such appear to have played no role.

598-99 (1880). Short-lived nineteenth-century income taxes were not apportioned. Compare Pollock v. Farmers' Loan \& Trust Co., 158 U.S. 601 (1895) (invalidating unapportioned tax on income from property) w'th Springer v. United States, 102 U.S. 586 (1880) (upholding Civil War income tax as indirect excise tax).

144. R. Caplan, supra note 31 , at 68-69.

145. I examined P. Brest \& S. Levinson, supra note 104; G. Gunther, Constitutional Law (11th ed. 1985); W. Lockhart, Y. Kamisar, J. Choper \& S. Shiffrin, Constitutional Law (6th ed. 1986); and G. Stone, L. Seidman, C. Sunstein \& M. Tushnet, Constitutional LAW (1986).

146. L. TRIBE, supra note $29, \$ 5.2$ at $300, \$ 5.9$ at $318-19$.

147. Ackerman, supra note 32 , at 530 .

148. Id. at 530-36.

149. The historical facts in this paragraph are taken from R. CAPLAN, supra note 31, at 61-65. 
State legislatures, responding to popular pressure, called for a constitutional convention to consider the Amendment, and many state legislatures achieved de facto direct election through campaign pledges to support the candidate who got the most votes in a legally non-binding popular election. Resistance was concentrated in the United States Senate, where incumbents were threatened by a change in their electoral base. But the directly-elected successors of these senators had a different electoral base, and they owed little to their state legislatures. Whatever the original motivation, the Seventeenth Amendment is one more duly ratified shift of power from the state to the Federal level.

Thus, Nagel is right when he says that our understanding of federalism has shifted since 1787 . He is wrong to give the judges much credit or blame for that. He is certainly wrong to suggest that there is something illegitimate about it. Technological revolution, Givil War, and constitutional amendments shifted vast powers from the states to the Federal Government. The American people fought and died and repeatedly voted to change the founders' understanding of federalism.

\section{iII. The Gritique of Supreme Court Opinion Writing}

\section{A. The Formulaic Constitution}

Chapters 5-7 criticize the analytic techniques of Supreme Court opinions. Chapter 5 examines the rational basis test in equal protection doctrine, and chapter 6 examines standards of constitutional justification more generally. Chapter 7 generalizes further, examining the costs of the Court's compulsion to explain all of constitutional law in terms of multipart formulas.

Nagel's critique of form is powerful. Common to each of these chapters is a showing that the opinions often conceal or subordinate what is really at stake in a case. ${ }^{150}$ Thus, a statute may be condemned because it does not fit some rationale invented by lawyers for the state, even though it is perfectly rational for some other reason, not considered by the Court and sometimes not even argued by the state. ${ }^{151}$ A special case of this is a rational statutory compromise between conflicting purposes, condemned as irrational because it does not fit any of the purposes considered one at a time. ${ }^{162}$

There is a similar propensity to focus on collateral issues at more demanding levels of review. The Court scrutinizes details of the fit between legislative means and legislative ends, often including wholly hypothetical ends, but it devotes much less attention to the importance and constitutional legitimacy of those legislative ends. The Court seems to think that

150. P. 105.

151. P. 112.

152. Pp. 88-90. 
legislatures almost never have a bad idea, but that they have a terrible propensity to be overinclusive and underinclusive.

Of course the Court is not as stupid as Nagel's description of these opinions implies. When the Court ignores the real reason for a statute, it must be because the Court has decided that the real reason is of dubious constitutional weight or legitimacy. One of Nagel's better examples is Eisenstadt $v$. Baird, ${ }^{153}$ which invalidated a ban on the sale of most contraceptives to unmarried persons. That case is comprehensible only as a holding about the state's interest in deterring premarital sex. The Court had to find that interest either constitutionally illegitimate, or insufficient to justify imposing the risk of unwanted parenthood. Another of Nagel's examples is Erznoznik v. City of Jacksonville, ${ }^{154}$ which struck down a statute forbidding visible nudity in outdoor theaters. That decision is comprehensible only as a holding that the offense to neighbors and passersby is insufficient reason to justify burdensome regulation that might make some movies less available to customers desiring to see them.

Yet my account of these cases bears little resemblance to either opinion. In Eisenstadt, the Court's opinion declared that less-than-absolute restrictions on the sale of contraceptives were not rationally related to any of the state's supposed goals. Nagel's analysis of this explanation is devastating. ${ }^{155}$

In Erznoznik, the Court said that nudity had been improperly singled out from other offensive speech on the basis of content, ${ }^{156}$ and that banning visible nudity was overinclusive as a means of protecting minors ${ }^{157}$ and underinclusive as a means of preventing traffic accidents. ${ }^{158}$ The Court did note that citizens in a pluralistic society must put up with offensive speech, that persons offended by movies could avert their eyes, and that the ordinance would deter the showing of movies with nudity. ${ }^{158}$ But these fundamental points were not presented as fundamental; they were presented as explication of the supposed main point about content discrimination.

Content discrimination cannot really be the main point in Erznoznik; if it is, the opinion collapses in contradiction. The Court assumed that the state could restrict all offensive speech on the basis of its content, for offensiveness is a content-based category. Having assumed that, the Court forbade further content discrimination within the category. Thus, the holding that the state could not discriminate against nudity is inconsistent with the assumption that the state could discriminate against offensive

154. 422 U.S. 205 (1975).

155. Pp. 88-90.

156. 422 U.S. at 211 .

157. Id at 212-14.

158. Id. at 214-15.

159. Id. at 209-12. 
speech. Moreover, the Court is surely not committed to either of these positions. The Court would never uphold a general ban on offensive speech. ${ }^{160}$ But it would uphold content discrimination against nudity in some contexts, including contexts with greater First Amendment significance. Consider the Court's likely reaction to nude guerilla theater on the Mall. ${ }^{161}$

Nagel's demolition of these opinions merely highlights the real question. If the Court emphasizes reasons that are hard to take seriously, we must ask why the Court will not emphasize its real reasons.

Nagel is most effective in chapter 7, where he condemns "the formulaic Constitution." The modern Supreme Court tends to convert every constitutional right into a formula, usually a three- or four-part test. Most of the Court's effort is devoted to the essentially legislative task of devising these formulas, each to govern a large category of cases. Much less effort is devoted to deciding individual cases. The first step in any case not clearly subject to an existing formula is to choose the standard of review. The choice of a standard of review is generally divorced from the facts of the case, and often consumes the bulk of the opinion; ${ }^{\mathbf{1 6 2}}$ applying the resulting standard to the facts is a tag end or a problem to be dealt with on remand.

This approach to opinion writing has many pernicious consequences. It substitutes dull and lifeless prose for the powerful language of the Constitution. ${ }^{163}$ It substitutes a regulatory perspective for a judicial one, a focus on a whole set of cases for a focus on this case. ${ }^{164}$ It produces abstract opinions-opinions that are abstracted both from the facts of the case and from the moral values at stake. ${ }^{165}$ It makes the issues before the Court seem technical, beyond the understanding of ordinary citizens. ${ }^{166} \mathrm{It}$ compartmentalizes cases into a series of tests, or hurdles, to be considered one at a time. "The compartmentalization so characteristic of the formulaic style impoverishes the Court's moral discourse . . ."167

I would add some additional characteristics of the formulaic style, im-

160. See, e.g., Hustler Magazine, Inc. v. Falwell, 484 U.S. 46 (1988) (satirical description of incest in outhouse); FCC v. Pacifica Found., 438 U.S. 726, 745-46 (1978) (plurality opinion) ("Some uses of even the most offensive words are unquestionably protected."); Eaton v. City of Tulsa, 415 U.S. 697 (1974) ("chicken shit"); Cohen v. California, 403 U.S. 15 (1971) ("Fuck the Draft"); Cantwell v. Connecticut, 310 U.S. 296 (1940) (anti-Catholic hate literature).

161. See Erznoznik, 422 U.S. at 211 n.7 ("No one would suggest that the First Amendment permits nudity in public places," " (quoting Roth v. United States, 354 U.S. 476, 512 (1957) (Douglas, J., dissenting))); id. at 223 (Burger, C.J., dissenting) (nude actors in park or street could be prosecuted). For further analysis, see Levinson, Freedom of Expression in Contemporary American Constitutional Law, in LiberTy of Expression 45, 49-56 (P. Cook ed. 1990).

162. P. 148.

163. Pp. 126-27.

164. Pp. 148-50.

165. Pp. 150-53.

166. Pp. 139-42, 155.

167. Pp. 152-53. 
plicit in Nagel's account but not emphasized. If the opinions are taken seriously, the effect of the formulas is to forfeit the advantages of the case method. The case method's strength is that rules are built up inductively from the facts of individual cases. But these opinions develop the rule in the abstract, without being informed by the facts of the case, and then apply the rule to the facts. I do not believe the Justices really think in that order; I am sure their reaction to the facts still plays a major role. But that means only that the opinion is still further removed from their real reasoning.

Part of the appeal of the formulas is that they imitate careful and detailed legal analysis. To analyze a constitutional requirement-in the formal sense of "analyze," meaning to break the requirement down into its non-overlapping component parts-is a useful step. Law teachers constantly struggle to get their students to do this. Such analysis can focus attention on issues that might be confused or overlooked, and clarify what various arguments and items of evidence are intended to prove. Even when a formula merely identifies the important separable elements in a balancing test, it can usefully structure the inquiry.

But few of the Supreme Court's formulas do either of these things. The formulas are often constructed from snippets of old opinions, with each snippet erected into an independent test. Nagel illustrates this process when he traces snippets from National League of Cities ${ }^{\mathbf{1 6 8}}$ into the shortlived four-part test for Federal regulation of state and local employees. ${ }^{\mathbf{1 6 9}}$ I have illustrated the process elsewhere by tracing the origins of the Court's establishment clause formula. ${ }^{170}$ Such snippets did not originate as a coordinated test and are unlikely to be either cumulatively complete or mutually exclusive. They were not designed as a formula, and their character is wholly changed when they are converted into one. In the establishment clause example, creation of the formula changed the substantive meaning of the snippets. Phrases that originated as explanations of neutrality were converted into separate elements of a test that seemed to forbid any significant benefit to religion, even where the effect of withholding a benefit was to inflict disproportionate harms. ${ }^{171}$

Creating formulas out of snippets of old opinions has the advantage that there is a pre-formula period when the Court visibly grapples with the facts of cases. The formula is derived from the snippets that emerge from that grappling. But increasingly, the Court bypasses this process and artificially constructs a multi-part test out of its head, as in Nagel's examples of opinions devoted to choosing the standard of review. Neither

168. 426 U.S. 833 (1976).

169. Pp. 135-36.

170. Laycock, supra note 128 , at $1380-81$.

171. Laycock, Formal, Substantive, and Disaggregated Neutrality Toward Religion, $39 \mathrm{DE}$ PaUL L. Rev. (forthcoming 1990). 
method has resulted in formulas that can plausibly claim to capture the essence of the constitutional clause allegedly being interpreted. That is the ultimate problem with the formulas. They lack "persuasiveness as an interpretation of constitutional text."172

Again there are counter-examples-opinions that address the issue and the competing interests more openly. ${ }^{173}$ It is even possible to describe the dominant pattern differently; Alex Aleinikoff describes modern Supreme Court opinions as establishing an age of balancing. ${ }^{174}$ Nagel and Aleinikoff legitimately cite many of the same opinions, because a frequent element of the Court's multi-part test is some threshold requirement for the weight or substantiality of the government's interest. Aleinikoff emphasizes the requirement of a substantial interest and sees balancing; Nagel looks at all three or four requirements and sees a formula. They are both right.

But Nagel has captured something important about why Supreme Court opinions are so often unsatisfying. The effect of breaking balancing tests into separate assessments of the weight of the state's interest, the fit between ends and means, the burden on the constitutional right, the possibility of less restrictive means, and so on, is to subordinate and obfuscate the striking of the balance. The Court prefers to rest its decision on one of the other elements of the formula; it rarely strikes down a law on the stated ground that the government's interest is not sufficient.

There are several reasons why Supreme Court opinion writing has taken its modern turn. The legislative tone of the opinions is partly an inevitable response to the difficulty of supervising all of Federal law, administered by thousands of state and Federal judges, through a mere one hundred fifty opinions each year. ${ }^{175}$ The Court may have decided that working out the law slowly through the case method is a luxury it can no longer afford.

Another reason is that the Justices work under difficult conditions. Opinions with odd explanations and opinions avoiding the real issue must partly reflect the difficulties of group decision-making ${ }^{\mathbf{1 7 6}}$ and the intense time pressures at the end of each Term. The Justices may be confident of a result, and able to agree on a result, without being able to think through or agree on every step of the explanation.

Another cause is that most constitutional law casebooks are forced by coverage pressure to print only a small part of most opinions. The Court's formulas always survive the editing process. Supreme Court clerks mas-

172. P. 143.

173. Pp. $98-102$.

174. Aleinikoff, Constitutional Law in the Age of Balancing, 96 YALE L.J. 943, 963-72 (1987).

175. See Scalia, The Rule of Law as a Law of Rules, 56 U. CHI. L. Rev. 1175, 1178-79 (1989); Strauss, One Hundred Fifty Cases Per Year: Some Implications of the Supreme Court's Limited Resources for Judicial Review of Agency Action, 87 CoLum. L. REv. 1093 (1987).

176. See supra text accompanying notes 25-26. 
tered those formulas and were rewarded with high grades; the formulas may be the only way they know of doing constitutional law. In chambers where the clerks write the opinions, the formulaic Constitution may be self-perpetuating.

Each of these reasons contributes to the problem of the formulaic Constitution. But I am not convinced that they explain the persistence with which the Court de-emphasizes what is really at stake in cases. What does explain it is the widespread failure to recognize the analytic structure of constitutional rights.

\section{B. The Structure of Constitutional Rights}

The persistent theme in Nagel's three chapters on the Court's opinions is that the Court tends to avoid talking about the central issue in its cases. It almost never says that a legislative goal is constitutionally illegitimate; only occasionally does it say that a legislative goal is not important enough to override an apparent constitutional right. It rarely says such things because to do so invites attack from a host of scholars who believe that the Court is not supposed to decide questions of substantive value. ${ }^{177}$ Nagel's book is merely one manifestation of that belief.

If the Court cannot admit to deciding anything important, it can shield itself by talking about whether means fit ends, whether the issue is one that requires a compelling fit, or a tailored fit, or merely a rational fit, and so on through all the dreary prose of the formulaic Constitution. But however it writes the opinion, the Court cannot avoid deciding whether the legislative goal is constitutionally legitimate and important. Those are the questions ultimately committed to judicial review. There is no reason to second-guess legislators on whether legislative means achieve legislative ends. But there is every reason to second-guess legislators on whether they have interfered with constitutional ends. As another reviewer noted, the rational and effective pursuit of evil is still evil, so that rationality and means-ends scrutiny offer "specious protection" of constitutional rights. ${ }^{178}$

Nagel's account is not that different from mine, except that he thinks the disabling attacks on the Court are legitimate. He sees the formulaic Constitution as an attempt to conceal judicial discretion, ${ }^{179}$ and to fit the opinions somewhere between formalism and realism, both of which he considers discredited. ${ }^{180} \mathrm{He}$ thinks that "mechanical" appeals to the constitutional text "have long been discredited as aridly conceptualistic and

177. Seminal formulations of this view include: Bork, Neutral Principles and Some First Amendmint Problems, 47 IND. L.J. 1 (1971); Gunther, The Supreme Court, 1971 Term-Foreword: In Siaich of Ezoling Doctrine on a Changing Court: A Model for a Newer Equal Protection, 86 Harv. L. REv, 1 (1972); Wechsler, Tou'ard Neutral Principles of Constitutional Law, 73 Harv. L. REV. 1 (1959).

178. Lupu, supra note 41 , at 956 .

179. P. 147.

180. P. 129. 
hopelessly literalistic," while "bald "balancing' tests . . . too obviously separate the Court from its sources of legitimacy." 181 He appears to assume that all appeals to text are mechanical, and that all balancing tests are bald. But the claim that balancing tests separate the Court from its sources of legitimacy is an unexplained ipse dixit.

A hint at the explanation appears in another passage, on the structure of constitutional rights. Nagel is perplexed that a wide array of constitutional doctrines fit into the same analytic pattern: "[T]he government must justify its rules by articulating a sufficiently important purpose and by demonstrating that the rule in some degree will actually achieve that purpose." ${ }^{182} \mathrm{He}$ finds it implausible that all the different clauses of the Constitution "could be anchored in some single generic value." the Court's recurring approach to constitutional interpretation cannot be so broadly applicable, and must not be derived from the Constitution.

Of course it is implausible that all constitutional rights serve the same generic value. But it is not implausible that all or most constitutional rights present an analytically similar question of justification. Each guarantee of a constitutional right forbids government to do something. Usually the prohibition is stated in sweeping terms, and often in absolute terms. The Court might have enforced these prohibitions literally, disabling government from ever abridging speech or impairing a contract, no matter how great the need. But that would have been unworkable, discrediting judicial review and forcing defiance or constitutional amendment. Instead, the Court has implied exceptions.

It is only with respect to these implied exceptions that the common analytic pattern emerges. The first step in constitutional adjudication is to decide whether the challenged government action falls within the scope of one of the Constitution's prohibitions. The pattern that so puzzles Nagel does not apply to this step of constitutional analysis. The Court asks very different questions in deciding whether a challenged statute abridges speech, or prohibits free exercise, or impairs the obligation of a contract, or discriminates between two persons similarly situated. These questions do reflect the variety of values that underlie different constitutional rights.

But once one of these questions is answered in the affirmative-once the Court finds an apparent violation of one of the Constitution's sweeping prohibitions-then we get to the recurring pattern of analysis that so puzzles Nagel. Then the question is: Is there a governmental need so important that it justifies an implied exception to an expressly absolute constitutional right? That is the question in speech cases, in religion cases, in contract clause cases, and in equal protection cases. Sometimes the stan-

181. P. 129.

182. Pp. 106-07.

183. P. 108. 
dard is modified because the prohibition is not absolute. Judicial process need be only that which is "due;" searches must be not "unreasonable"; takings must be with compensation that is "just." In these clauses, the standard of justification is reduced, but the form of the question is the same-is there justification for the government's action sufficient under the standard stated in the relevant clause? Sometimes the constitutional prohibition is implied from more general provisions, as in the family and sexual autonomy cases. But once such a prohibition has been implied, and a case falls within its scope, the question of justification takes the same form.

Thus, sweeping prohibitions subject to implied exceptions for reasons of necessity form the structure of constitutional rights. One of the Court's essential tasks is to decide governmental claims that it is necessary to make an exception to some apparent constitutional right. It is not at all surprising that the Court approaches all these claims by asking whether the benefits to the government justify the exception.

What is surprising is that the standards vary as much as they do. Elsewhere Nagel wonders why some implied exceptions require compelling reasons, some substantial reasons, and some merely rational reasons. ${ }^{184}$ $\mathrm{He}$ is right to wonder about these varying standards of justification; they are textually inexplicable. When the standard for justifying implied exceptions to textually absolute rights varies from toothless rational basis to strict-in-theory but fatal-in-fact, the Court is simply picking and choosing the constitutional rights it wants to enforce.

The proper standard for implied exceptions to absolute rights should be something like the compelling interest test. An implied exception to a textually absolute right should be an extraordinary thing. We have learned from experience that "no law" cannot literally mean no law. But "no law" should mean hardly any law-as few laws as possible. Courts should adhere as closely as possible to the text they are enforcing.

Whatever the standard of justification, the structure of constitutional provisions leads directly to a certain kind of balancing. Obviously I do not mean balancing in which the commands of the Constitution are reduced to good advice, in which the Constitution is just one interest among many. This is the sort of balancing that Alex Aleinikoff so effectively condemns. ${ }^{186}$ Rather, I mean that the justification for implied exceptions to constitutional rights inevitably depends on the urgency of the need for the exception and on the importance of the exception to the constitutional right. Courts should ask whether the cost of enforcing the apparent constitutional right in each case is so grossly disproportionate to the constitu-

185. Aleinikoff, supra note 174 , at $986-92$. 
tional benefit that it would be essentially intolerable to enforce the text absolutely.

Aleinikoff argues that such implied exceptions to constitutional rights do not require balancing at all. ${ }^{186}$ But in this I think he errs. Courts will inevitably create exceptions in such compelling cases, and the exceptions will be narrowest if they are explained in precisely the terms that motivate the Court. If we require the Court to invent "principled" reasons broad enough to include all the exceptions it feels compelled to make, the result will be ill-fitting proxies that sweep in less compelling exceptions as well. Aleinikoff's insistence that the Court avoid balancing even in such extreme cases mirrors Nagel's attack on balancing from the other side of the political and jurisprudential spectra, and it produces similar pressures to avoid discussing the real reasons for decision.

Far from separating the Court from its sources of legitimacy, balancing is inevitable. Balancing is the restrained judicial response to the sweeping and often absolute constitutional text. Explicit balancing tends to force the Court to deal with the facts of each case before it, ${ }^{187}$ and thus tends to reinforce the virtues of the case method, although the Court can balance in broad categories when it chooses.

Honest balancing would not eliminate multi-part tests, although I think it would make them fewer and simpler, and it would certainly make them more candid. There would be much less talk of fit between means and ends, and much more talk about the value choices that drive decisions. Honest balancing would force the Court to talk about the value of the constitutional right and the way in which and the extent to which the challenged government action impairs the right. Government goals that depended on a rejection of the constitutional right would be illegitimate, and the Court would sometimes have to say so. More often, government goals would be legitimate, but not important enough to justify overriding an express constitutional right, and the Court would have to say that. Sometimes, the goal would be legitimate and important, but the challenged statute would not benefit the goal enough to justify overriding the constitutional right. Only this last set of cases bears any resemblance to means-ends scrutiny. And even here the resemblance is superficial. The ultimate issue in such cases is whether the statute does enough good to justify implying an exception to the express constitutional right. The fact of an express constitutional right should weigh very heavily in the balance; it should take a powerful showing of necessity to imply an exception.

When the Court condemns a statute as irrational, or ill-suited to its ends, it denigrates the statute and avoids the need to consider competing 
interests. If instead the Court conceded that even unconstitutional statutes usually serve plausible ends in a plausible manner, holdings of unconstitutionality would require renewed explanation of the importance of the right at issue and why it is that only the most compelling interests can override it.

The Court rarely writes its opinions this way. Too many critics have said the Court is not supposed to decide which goals are legitimate and which are important. Certainly the political branches have a much more general mandate to decide what is important. But in the context of constitutional rights, legitimacy and importance are at the core of what courts must decide, and we would all be better off if they did it explicitly.

\section{CONCLUSION}

Nagel powerfully describes the results of the Supreme Court's efforts to hide the ball, and he sometimes even sees that hiding the ball is part of the problem. But his solution would be to abandon the ball game. He does not see that the ball should be out in the open. He cannot see the legitimacy of balancing, because he does not see the structure of constitutional rights. $\mathrm{He}$ does not see how constitutional law repeatedly requires the Court to demand justification for the need to invade sweeping constitutional prohibitions. He does not see the structure because he does not see the sweeping prohibitions in the first place. He does not see sweeping prohibitions because he refuses to take them seriously-because he considers sweeping prohibitions too "general and cryptic"188 to be credited.

Nagel cannot understand vigorous judicial review because he sees so little meaning in the constitutional text, and he places so little value on the rights of individuals. Not surprisingly, it is hard to explain an institution without considering its principal source of authority and its principal reason for existence. 
